\title{
Fair Trade, Diversification and Structural Change: Towards a broader theoretical framework of analysis $^{1}$
}

\begin{abstract}
This paper responds to the argument that while Fair Trade governance might increase short-term welfare, it reduces long-term development prospects by discouraging diversification and structural change. Even though it is agreed that lower value sectors, such as commodity agriculture, are unlikely to offer a long-term solution to global income inequalities, the importance of their short- and medium-term contributions cannot be ignored by analysis. Furthermore, critics have evaluated Fair Trade governance against the benchmark of perfect market organisation. However, given the realities of the developing world, dismantling Fair Trade abandons poor producers not to theoretical free markets and successful diversification, but to market failures, capability constraints, and risk management issues - all of which present serious obstacles to beneficial change. In this light, analysis of FLO Fairtrade is used to argue that far from being detrimental, Fair Trade might actively contribute to diversification by alleviating some of the real world obstacles that otherwise retard development.
\end{abstract}

\footnotetext{
${ }^{1}$ The author would like to thank Mark Hayes, Adrian Morley, Roberta Sonnino and two anonymous referees for taking the time to offer very helpful comments on earlier drafts of this paper. However, the author naturally takes full responsibility for the final content, and therefore any contentions or inaccuracies that the reader may find within. A further acknowledgement is to the ESRC who provided the author with studentship support during the development of this work.
} 


\section{Introduction}

As sales of Fair Trade products have grown (FLO 2007) so has the corollary academic interest in this phenomenon Starting with Michael Barratt-Brown's seminal work (1993), the theoretical and empirical understanding of Fair Trade has become increasingly sophisticated and it is to this former area that this article hopes $\mathfrak{b}$ contribute. Recently it has been noted that, "At the origins of F[air] T[rade], there is the intent of setting up a new regulation framework for commercial exchanges" (Becchetti and Huybrechts 2008, p. 735), and it is on this basis that this paper interprets Fair Trade as a system of private "governance" that organises the production and trade for specific commodity goods. The aim of such governance is to increase the benefits of these commercial activities for southern producers; a group seen to be marginalised and even exploited by "conventional" governance arrangements (Barratt Brown 1993; Nicholls and Opal 2005).

Such an interpretation of Fair Trade is grounded in the recognition that far from being solely organised by market forces, economies are governed by a variety of power networks (Powell 1991; Thorelli 1986; Williamson 1975). Applying these ideas to value chains, Gereffi (1995, p. 84) suggests that market governance is just one of five ways in which commercial interactions are organised - and are thus only one system among many that coordinates the economy. A further nuance sees governance as

\footnotetext{
${ }^{2}$ The term "conventional" highlights the argument that while the debate about Fair Trade is often couched in terms of "free trade versus Fair Trade", this does not represent the policy option available. As Barrat Brown (1993) made clear, the very purpose of Fair Trade was to compensate for the effects of monopolistic and oligopolistic structures that dominate the commodity sectors. In other terminology, Fair Trade essentially seeks to replace "captive" governance, in which a small number of buyers capture the function of price giver, with a "relational" form of inter-firm coordination that considers the situation of producers in structuring the terms of interaction (Gereffi et al. 1995).
} 
operating both externally and internally to value chains (Kaplinsky and Morris 2002, p. 31). This is because while quality, price and timing are often controlled from within these networks, the rise of "private authority" (Hall and Biersteker 2002) means that many other none-state and none-market systems now influence quality standards - as well as the labour and environmental conditions under which production takes place (Kaplinsky and Morris 2002, p. 31). It is into this category of private governance that Fair Trade appears to integrate smoothly (as either internal norms of socially orientated companies or external regulation and certification for mainstream operations), and as such, it is the broad language of governance that will be used in this article.

While academic interest in Fair Trade has been as multifaceted as the concept itself, work has particularly focused on poverty reduction and developmental impact. This is because while Fair Trade goes beyond the governance of labour standards to set conditions such as prices, credit arrangements and capacity building ${ }^{3}$, advocates make the specific claim that, "Fair Trade contributes towards sustainable development" (F.I.N.E. 2001). While some analysis has been supportive of this position (Le Mare 2008; Strong 1997), many investigations have uncovered varying degrees of divergence between Fair Trade rhetoric and actual outcomes (Fridell 2007; Raynolds et al. 2007b; Taylor 2002), and a minority of scholars have offered even more critical

\footnotetext{
${ }^{3}$ More specifically, the generic concept of Fair Trade requires that: producer organisations aim to be sustainable and socially just; initial buyers pay prices that cover the cost of sustainable and just production; initial buying relations are stable and supportive; credit is provided upfront to assist with production; and that inputs are provided and managed in order to develop and expand the capabilities of producer groups and their associated communities. Such an interpretation is synthesised from summaries provided by Hira and Ferrie (2006, p. 108) and Moore (2004, p. 73), as well as the wider literature on Fair Trade theory and practice.
} 
conclusions (Moberg 2005; Sick 2008; Smith 2007b). Perhaps the most persistent and vocal criticism is that while Fair Trade might be well meaning in its poverty alleviation and environmental agenda, it "retards the diversification of production that is fundamentally necessary for the economic advancement of developing countries" and, "promotes continued reliance on products that are arguably poor prospects in the long-run" (LeClair 2002, p. 957). This view is based on the argument that by paying guaranteed minimum and above market prices, Fair Trade governance incentivises producers to remain in sectors that offer little bng-term opportunity to increase value-added. While this theoretical argument was originally made in the context of handicrafts (LeClair 2002), it has been continually reproduced (Booth and Whetstone 2007; Collier 2008, p. 163) and now applied to the agricultural goods (Sidwell 2008) that make up the majority of the Fair Trade market. As is explained below, reference to commodity agriculture makes this a particularly powerful critique given the decline in the terms of trade vis-à-vis more highly processed and manufactured goods.

While only a limited volume of empirical evidence directly informs this discussion, there is a large amount of work that deals with the underlying issues as they emerge in other contexts. Thus, the approach of this paper is to draw on this wider literature to question the argument that Fair Trade will naturally hurt the long-term interests of producers, and to propose an alternative approach to evaluation. Based on this wider literature, it is argued that despite the need for diversification, current criticism of Fair Trade is based on a number of inappropriate assumptions. Firstly, while agriculture is unlikely to generate the growth needed to reduce north-south income inequality, this does not mean that its important short- and medium-term contributions can be 
discounted; especially where individual firms and whole countries currently have few opportunities to compete effectively in other sectors.

Secondly, the critique of Fair Trade is based on deductive economic reasoning which evaluates real life practice against perfect market theory. Such an approach views Fair Trade as "interventionist" policy that "distorts" the efficient operation of "perfect markets" and retards diversification. However, even a cursory glance at wider evidence reveals that, in reality, the policy choice is not between effective perfect markets and distorting intervention, but between market failures - empirically proven to retard diversification - and some form of compensating intervention (either politically or culturally constructed). Furthermore, even when markets do exist, theoretical evaluation has ignored two of the most well established barriers to producer diversification: the need to manage livelihood risk and uncertainty (versus the assumption of perfect information and production decisions isolated from consumption requirements); and the degree of capabilities possessed by actors (which is ignored when emphasis is placed on incentive structures alone). When these factors are considered, the premise of evaluating Fair Trade against perfect market theory emerges as inappropriate, and instead it appears more helpful to compare the principles of Fair Trade against what actually exists in its absence. In this light, the a discussion of FLO Fairtrade ${ }^{4}$ hypothesises that far from retarding diversification, Fair

\footnotetext{
${ }^{4}$ Where the term "Fair Trade" refers to the generic concept, "Fairtrade" refers to the specific interpretation of the Fairtrade Labelling Organizations International (FLO). Where Fair Trade has been applied as internal governance norms by some socially orientated organisations, FLO Fairtrade has provided a system of third party governance which offers a specific concretisation of these wider principles. It is this latter interpretation that has become the dominant version of Fair Trade in the market (by volume), and for this reason it is FLO Fairtrade is concentrated on below.
} 
Trade might in fact actively contribute to this essential process by overcoming problems of risk and capability deprivation.

\section{The Importance of Diversification and Structural Change: How might Fair Trade governance retard development?}

One well established facet of development theory is that while fixed or subsidised prices, resource transfers, and higher consumption might temporarily raise welfare, there is no guarantee that positive outcomes are sustainable ${ }^{5}$ Instead, poorer economies must generate endogenous economic growth by investing current resources in expanding value-added and increasing income; an aim that involves two processes that are subsequently seen as essential in the generation of sustained growth. The first is economic diversification which increases income at the level of the individual entrepreneur (Weinberger and Lumpkin 2007). In synthesis from the literature, it is suggested that three broad options are available (See Figure 1).

The second process necessary for the sustained generation of economic growth is "structural change"; and this refers to changes in the activities performed by the wider economic units (such as the region or country) in which individual producers are embedded (Lewis 1954; North 1981, pp. 45). Applying the above principles to the export sector (the major concern given the export orientation of Fair Trade goods), the promotion of higher value, non-traditional exports is widely endorsed as the optimum

\footnotetext{
${ }^{5}$ While the literature debates the short term merits of such policy instruments in a variety of contexts, particularly Latin American Import Substitution Industrialisation and East Asian export orientation, a general consensus notes that where there are benefits, these are contingent on the development of endogenous productivity (Baer 1972, 1984; Bhagwati 1988; Bruton 1998; Noland and Pack 2003; Prebisch 1963).
} 
strategy to generate endogenous growth (Bruton 1998, p. 920; Gereffi and Memedovic 2003) ${ }^{6}$. In this light, if Fair Trade is retarding the shift from lower to higher value producing, there is indeed strong ground on which to question its contribution to "sustainable development".

Figure 1.

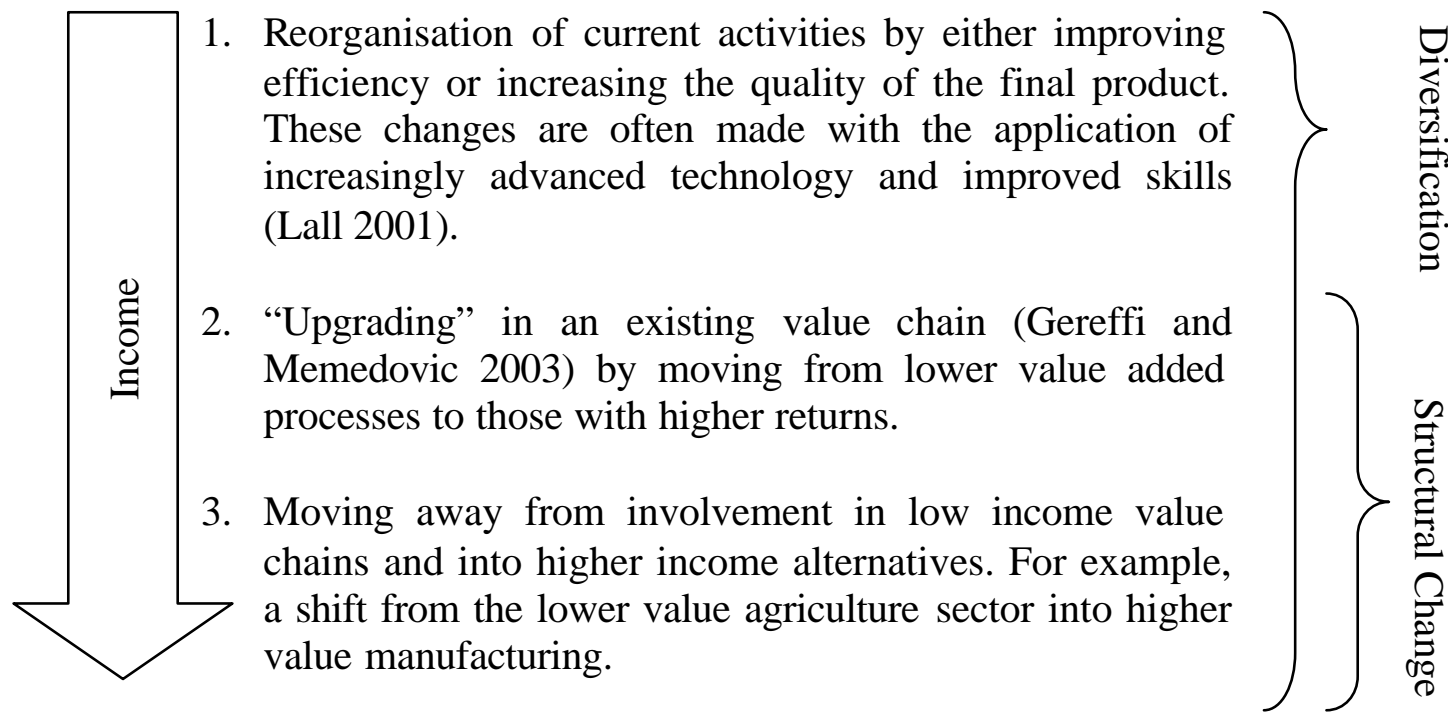

However, a key question in this debate concerns how these necessities of diversification and structural change are best facilitated. After Central State Planning and Import Substitution Industrialisation policies lost legitimacy (Bruton 1998) mainstream opinion has been divided into two camps: those who emphasise the merits of market governance generated through liberalisation (Winters 2003); and those who stress the need to "govern the market" (Wade 2005) in order to control the process more closely (Chang and Grabel 2004a; Stiglitz and Charlton 2005). The former group argue that as market prices reflect the balance between supply and demand they

\footnotetext{
${ }^{6}$ Especially given its contribution to avoiding balance of payment constraints on economic development (Thirlwall and Hussain 1982).
} 
provide an incentive structure to guide rational actors to the best investment opportunities. As a result, interventions in price mechanisms distort incentives and lead to suboptimal investment decisions. Conversely, the latter school of thought does not consider that free markets always meet the needs of specific groups (communities, regions or countries), and thus prefer intervention to ensure that outcomes are pro development - and not just pro private financial gain ${ }^{7}$.

While the literature that debates the transitions seen in many South East Asian economies (Bhagwati 1988; Chang 2002; Noland and Pack 2003; Wade 1990) is an excellent example of this divided opinion, the same issues emerge in the debate over Fair Trade. Specifically supporters argue that in the absence of other intervention, private governance is needed to ens ure that poor producers can gain from participation in an increasingly globalised economy (Barratt Brown 1993; Oxfam 2002; Raynolds et al. 2004). Critics of Fair Trade on the other hand argue that poor returns are due to oversupply and that as a result, producers must diversify away from current sectors to increase standards of living in a sustainable way (LeClair 2002; Sidwell 2008). As an extension they claim that the payment of guaranteed minimum prices above market rates will blunt the incentives for diversification and thus only serve to perpetuate poverty and inequality.

This is a particularly powerful argument when applied to the commodity agricultural goods that form the majority of the Fair Trade market, as the real prices of these

\footnotetext{
${ }^{7}$ Numerous authors, starting with Fredrick list in 1941 (Dunkley 2004, p. 51), have made the point that the market allocates resources on the basis of private profit and that there is no reason why this private financial returns will equate with developmental or social returns (Chang and Grabel 2004b, p. 155; Rodrik 2004).
} 
goods have been in long-term decline vis-à-vis those of more highly process and manufactured exports (Ocampo and Parra 2003; Prebisch 1950; Singer 1950). Indeed, it has been the discovery of the falling terms of trade that has largely underpinned the mainstream policy recommendation that countries shift away from raw and agricultural goods and towards more highly processed and preferably manufactured exports (Bruton 1998). Based on this assessment, perhaps the most damming criticism of Fair Trade is that it perpetuates a structural division of labour that stands to see the rich getting richer and the poor consistently loosing out (Frank 1966; Wallerstein 1979).

\section{The Importance of Agricultural Development: Investment in agriculture is no dead end}

While evidence of a decline in the terms of trade is strong, research also validates Prebisch's (1950) explanation that price patterns are defined by market determined qualities of a good, and not just its physical characteristics (although the latter does clearly inform the former). For example, Schrank (2004) shows that while many East Asian countries profited from manufacturing garments, attempts to copy this success have often failed. This is because as more countries pursue the same agenda, supply rises and international prices fall - a process that scholars have now identified in numerous manufacturing sectors (Fitter and Kaplinsky 2001, p. 2; Wood 1997).

Furthermore, while agricultural prices are in long-term decline of about $1 \%$ per year, this is not continuous or universal, and as a result, some agricultural goods still offer more value-added than others (Ocampo and Parra 2003). As in the case of switching to horticulture (Weinberger and Lumpkin 2007) these might involve fundamental 
changes to the physical nature of the product produced. However, other examples such as the "Golden Kiwi" show that higher prices can also be engineered through appropriate social construction that requires little or no physical change (Fitter and Kaplinsky 2001). A more mixed example might be organic agriculture where additional value lies in both social and physical differentiation of the product (Kilian et al. 2006; Thompson 1998). Particularly of note in this process has been the transition of grades and standards, accompanied by labelling and certification, "from a technical instrument to reduce transaction costs in homogeneous commodity markets to a strategic instrument of competition in differentiated product markets" (Reardon et al. 2001, p. 421). Indeed, it is widely recognised that the rise of both organic and Fair Trade items have relied heavily on these methods to differentiate themselves in the market place (Tran-Nguyen and Zampetti 2004) ${ }^{8}$.

What these examples show is that far from being a universally poor option, appropriate investment in a dynamic agricultural sector might not only contribute to domestic food security (by increasing local food production and reducing reliance on volatile international markets), but can also contribute positively to the balance of trade. Such an intra-sectoral view might well help to explain the observation that while income increases for rural households can be correlated with a decrease in nonfarm activity (Hymer and Resnick 1969), other cases show that appropriate investments in agricultural activities can also increase returns (Chuta and Liedholm 1990; Mellor 1976).

\footnotetext{
${ }^{8}$ Given the self reflexive component of sustainable development there is a reason to deconstruct the concentration on supply side structural change and suggest that diversification of northern demand should also play a part in building endogenous growth in poorer regions. However, for simplicity, this is not an issue that will be addressed here.
} 
However, the argument in favour of agricultural investment is more extensive. This is because the appropriate development of agriculture (or indeed any sector such as handicrafts) offers an opportunity for poorer countries to accumulate general capabilities or "agglomerate" the assets needed for sectors that offer categorically higher returns (Porter 2000). Indeed, comparisons of economic growth and sectoral development show that as poor countries get richer, sectoral production and employment become less concentrated and more diversified as the number of nontraditional exports expands (Imbs and Wacziarg 2003; Klinger and Lederman 2004). Such patterns suggest that as returns from traditional activities are invested in essential economic assets (such as infrastructure, education, health and knowledge $)^{9}$, involvement in more and more non-traditional activities becomes possible. This understanding helps explain why economies that have diversified out of commodity exports have only done so after accruing extensive levels of infrastructure, higher levels of labour and technical skills and better access to financial resources than those that have not (Maizels 2003, p. 176).

In further support of the importance of agricultural investment it must be also noted that while a shift to manufacturing might be a long-term necessity, many countries such as those in Africa simply have no such choice in the short- or medium-term (Wood 2003; Wood and Mayer 2001). With low levels of human and physical capital (not to mention inadequate infrastructure) Africa has little hope of entering

\footnotetext{
${ }^{9}$ Indeed, while the development of infrastructure used to be of prime concern, it is now recognised that this is unlikely to be enough (Krueger 1995, p. 23) as education (Borensztein et al. 1998; de Mello 1997) and health (Anand and Sen 2000; Bhargava et al. 2001; Bloom et al. 2004) all play important roles in stimulating productivity.
} 
international markets for manufactured goods on a competitive basis. As a result, the only currently viable policy option is to invest in commodity sectors as the economic engine of further development - very much as South East Asia invested in agriculture prior to the subsequent growth of their own manufacturing sectors (Kay 2002).

So strong is this argument that even the World Bank (which has largely ignored the importance of agricultural development) has joined other major institutions such as the UK Department for International Development (2005) in rediscovering the importance of agricultural investment. Indeed, the World Development Report 2008: Agriculture for Development notes that, "The top priority is to generate rural jobs by diversifying into labor-intensive (sic) high value agriculture linked to a dynamic rural nonfarm sector in secondary towns" (World Bank 2008a, p. 1).

\section{The Case for Fair Trade: The problems with "conventional" governance}

While agriculture appears central in the process of developing economies, this argument still explicitly and implicitly recognises the need for diversification if endogenous growth is to rise over time. As a result the important question is how to facilitate such change, and the position of Fair Trade critics is that the payment of minimum prices will only serve to distort markets and thus corrupt investment decisions. However, such a view assumes a choice between suboptimal outcomes under Fair Trade and preferential results achieved through deference to perfect market organisation - and it is here that analysis based on deductive economic theory is open to question. 
As Polanyi (1985 [1944]) observed, despite the tendency for markets to widen and deepen over time, markets cannot be guaranteed to exist, and the completeness of the Great Transformation has been consistently questioned (Granovetter 1985; Inglehart and Baker 2000). Indeed, it was noted in 1989 that, 'it is now well recognised that there are many instances of market failures in more developed economies... [but also that] market failure is even more prevalent in L[ess] D[eveloped] C[ountrie]s" (Stiglitz 1989, p. 197). Despite the realisation that "information" is the "good" most subject to market failure, development policies are still judged against the hypothetical outcomes of perfect market models; a scenario that unrealistically assumes free information flows, and as a consequence rather unhelpfully eradicates consideration of risk and uncertainty from decision making models.

It is on this basis that the comparison of Fair Trade governance and perfect market operation becomes inappropriate, as, "It is well recognized (sic) that, in the developing country context, rural households are systematically exposed to market imperfections and constraints... and their behavior (sic) cannot be understood without reference to the specificity of these failures" (de Janvry and Sadoulet 2006). As a consequence, and despite opportunities identified by macro level analysis, what is often more important (especially in the case of small farmers) is the level of opportunity occurring at the local or meso level- a point first established by Alfred Marshall in 1890 and continually revisited by economic geographers and those working with the concepts of agglomeration and clustering (Porter 1990). Such a focus shows that new firms generate "sequential externalities" (Murphy et al. 1989) as they provide upstream markets and downstream suppliers around which other firms 
can concentrate. However, where forward or backward linkages are missing there are no immediate markets where inputs can be purchased and outputs can be sold. This situation requires entrepreneurs to take considerable risks, to rely on coordinated investment in new supply chains, or in the absence of these interventions, leaves economies with serious market failure issues that retard diversification initiatives (Rodrik 2004).

To place this theory in the context of Fair Trade, it can be hypothesised that a coffee farmer will want to respond to the international price incentives to shift from coffee into horticultural output (Weinberger and Lumpkin 2007). However, in the local area there are no suppliers of inputs such as seeds or specialist equipment, nor local access to exporters dealing with such products. Furthermore, the knowledge required to make such investments is also unlikely to be supplied by the market. Thus, despite theoretical price incentives, diversification is not a feasible income strategy to a rational individual.

This means that while removing Fair Trade governance would sharpen "distresspush" incentives for actors to diversify away from current activities (as price supports disappear), there is no guarantee that other "demand-pull" factors will exist in the local economy ${ }^{10}$. Such a situation is problematic as literature highlights that where diversification is facilitated by distress-push incentives it tends to exhibit characteristics of a "coping" strategy as new activities are low risk but also unlikely to increase income. This is contrasted to diversification for "accumulation" prompted by "demand-pull" incentives where new activities offer higher returns, and are of the

\footnotetext{
${ }^{10}$ For an explanation of the difference between distress-push/coping and demand-pull/accumulation diversification see Bezemer et al. (2005).
} 
type desired by the development theory above. Another point is that while lower prices might incentivise labour to leave agriculture for employment in the manufacturing sector, again, the realities of the developing world suggest humanitarian caution. As Hayes (2008, p. 2958) notes, contrary to the assumptions of theoretical models, the developing world is characterised by an excess of labour supply and thus Fair Trade exists "where the alternative is not a better employment of those assets and skills, but [simply] unemployment".

These local market failures are not the only barrier identified in wider literature to explain why diversification into higher-value activities will not occur even if the "prices are right". This is because while price systems indicate potential returns, all economic decisions must also factor in two further considerations: 1) issues of risk and uncertainty and; 2) the capabilities that actors have to respond to the theoretical opportunities communicated in price incentives.

\section{How Risk Retards Diversification}

While all economic decisions involve the management of risk and uncertainty (Knight 1921) this issue is especially true in the developing world. Poorer countries suffer from natural shocks (such as weather hazards and irregular rainfall), the failure of infrastructure, as well as human-made risks including political instability (Fafchamps 2003; Moschini and Hennessy 2001) and market volatility (Reardon et al. 1992). Furthermore the prevalence of market failure in the developing world, and especially rural areas (where Fair Trade mostly operates), means that there are limited market 
based means of managing such negative shocks (Stiglitz 1989) ${ }^{11}$. As a consequence, actors must find alternative methodologies to deal with risks to life and livelihood, and while associated strategies are numerous (often being part of cultural institutions), one widely used method is livelihood diversification ${ }^{12}$.

However, research in this area shows that due to the nature of their situation, rural producers constantly make trade-offs between "accumulation" and "coping" diversification strategies. This is because in reality farmers are not just producers but also consumers who must consider the need to smooth household consumption. This realisation informed a non-seperability model of analysis (Yotopoulos and Lau, 1974) which, in contrast to standard economic theory, recognises that consumption desires directly influence production decisions. Just as all those living next to a casino do not place all their savings on red at the first opportunity for a windfall payment, poor agriculturalists do not necessarily invest in production that offers the highest theoretical return; and this insight has important implications for those arguing that diversification should be left to emerge from "individuals voluntarily seizing market opportunities" (Sidwell 2008, p. 5).

This is because before potential returns can be secured, new income strategies must be rendered profitable through processes of "self discovery"13 and "learning by doing". As a result while some diversification options might bring improved returns, the

\footnotetext{
${ }^{11}$ Specifically, formal insurance markets, and credit - which is often used as a substitute (Eswaran and Kotwal 1989) - are largely inaccessible (Hoff and Stiglitz 1990, p. 235).

${ }^{12}$ For examples see: Fafchamps (2003), Kazianga and Udry (2006), Mordoch and Haley (2002), Rischkowsky et al. (2006), Rosenzweig and Stark (1989).

${ }^{13}$ This theory refers to the process of adapting any exist production processes to any new local conditions. For an introduction with empirical examples see Hausmann and Rodrik (2003)
} 
possibility of failure, at least for an interim period, is often very real. This is particularly relevant to agricultural diversification as the maturity of new crops is subject to time-lags as well as the information asymmetry produced by natural conditions.

Managing such risk and uncertainly is of course easier where outcomes can be guaranteed or insured (Peter 1992; Rodrik 2004). Comparatively, these risk are more easily shouldered by those with the capabilities to smooth their consumption in the meantime (through savings, access to credit or other social safety nets) and likewise by those involved in more stable sectors (Alderman and Paxson 1992). However, the irony is that the poorest and thus most in need of profitable diversification are the least able to risk such action (Bigsten et al. 2000). This is a characteristic of "the poor" embedded in the theory of "declining marginal utility" and a good explanation of why, "although it may be in their [the poors] long-term benefit to undertake a certain investment, short-term insecurity prevents the investment from being undertaken" (Ronchi 2000, p. 38). This evidence clearly suggests that while appropriate push-incentives are important, it cannot be assumed that they will result in profitable diversification by poor producers.

\section{How Capability Constraints Hinder Diversification}

Another real life consideration consistently forgotten in the persistent concern to "get the prices right" (World Bank 2008a) is the need to have appropriate capabilities in order to operationalise these incentives. Despite assumptions, even the most (seemingly) simple income strategies require financial, as well as physical, social and human capital. While financial capital is obviously unavailable to "poor" producers, 
the lack of other assets might be even more restrictive given that physical capital, social contacts and knowledge often only serve very specific purposes. In a vivid illustration it is noted that, "both an egg-beater and an aircraft carrier enter into the American national accounts as little bits of physical capital, and yet they are not interchangeable" (Putnam 2001, p. 117). In the same way, the physical capital used to grow coffee is not interchangeable with that needed to produce horticultural products (Smith 2007b, p. 94). This lack of substitutability is equally true of social capital (Putnam 2001), and the same point must be made about certain types of human capital; knowing how to use an egg-beater does not qualify you to control an aircraft carrier anymore than knowing how to grow coffee helps you understand the process of roasting your own.

Furthermore, the transfer of knowledge interconnected with technology is often “tacit" (Hausmann and Rodrik 2003), and thus cannot be easily codified, passed on or applied to new contexts (Evenson and Westphal 1995; Lall 2000). As Zehner (2002, p. 15) points out in his critique of Fair Trade, the recognition of social learning mechanisms as both "enablers" or "barriers" to diversification is of critical importance (See: Conley and Udry 2001). However, while Zehner contradicts the evidence by arguing that Fair Trade fails to recognise this (discussed below), he offers no reason why such information will flow better in a world where Fair Trade is absent.

These factors are further well established reasons why poverty levels are strongly correlated with a decreasing propensity to embark upon accumulative diversification strategies (Dercon and Krishnan 1996; Gilbert 1988; Kazianga and Udry 2006). In the 
light of these economic realities, emphasis on "push" price incentives is simply not adequate to evaluate or develop methodologies for promoting diversification Instead, this evidence suggests that the realistic and immediate alternative for many of those currently supported by Fair Trade is not effective markets and beneficial diversification, but market failure, exposure to risk, capability constrains and static economic structures. This argument is summarised in Figure 2 which illustrates the differences between theoretical expectations and real world conditions.

\begin{tabular}{|c|c|c|}
\hline & Perfect Market Theory & $\begin{array}{l}\text { Realities of the Rural } \\
\text { Developing World }\end{array}$ \\
\hline \multirow{3}{*}{ 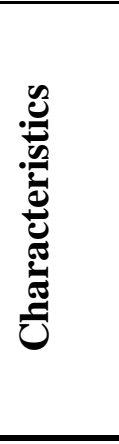 } & $\begin{array}{l}\text { Markets for all goods complete and } \\
\text { perfect }\end{array}$ & $\begin{array}{l}\text { Significant market failures } \\
\text { with missing demand-pull } \\
\text { opportunities and incentives }\end{array}$ \\
\hline & $\begin{array}{l}\text { Perfect information for all actors across } \\
\text { time and space }\end{array}$ & $\begin{array}{l}\text { Information subject to largest } \\
\text { market failures, patchy and } \\
\text { often non-existent }\end{array}$ \\
\hline & $\begin{array}{l}\text { Capabilities to respond to incentives not } \\
\text { considered }\end{array}$ & $\begin{array}{l}\text { Poor communities defined by } \\
\text { a lack of financial, physical, } \\
\text { human and social capital }\end{array}$ \\
\hline 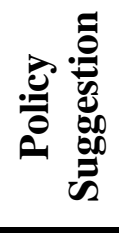 & $\begin{array}{l}\text { Defer to market incentives to promote } \\
\text { accumulating diversification strategies }\end{array}$ & $\begin{array}{l}\text { Compensating intervention } \\
\text { necessary to manage risk and } \\
\text { develop capabilities to } \\
\text { diversify }\end{array}$ \\
\hline
\end{tabular}

On this basis, the important question is not how Fair Trade compares to theoretical models, but if and how it compensates for the real world problems faced by poor producers. It is this question that is explored below using the example of FLO Fairtrade. 


\section{Building a Theoretical Case for Fair Trade: How FLO governance might influence real life diversification options}

While it is suggested above that the broad concept of Fair Trade can be defined by a number of generic norms of operation (See Footnote 3), FLO Fairtrade governance interprets such norms in more specific practices and rules. These interpretations are summarised in Figure 3.

\begin{tabular}{|c|c|c|}
\hline $\begin{array}{c}\text { Realities of the Rural } \\
\text { Developing World }\end{array}$ & Response of Fair Trade & $\begin{array}{c}\text { FLO Fairtrade } \\
\text { Governance }\end{array}$ \\
\hline $\begin{array}{c}\text { Significant market failures } \\
\text { with missing demand-pull } \\
\text { opportunities and } \\
\text { incentives }\end{array}$ & $\begin{array}{c}\text { Flows of information that } \\
\text { identify value added } \\
\text { opportunities }\end{array}$ & $\begin{array}{c}\text { Flows of information that } \\
\text { identify value added } \\
\text { opportunities through } \\
\text { Producer Business Unit }\end{array}$ \\
\hline $\begin{array}{c}\text { Information subject to } \\
\text { largest market failures, } \\
\text { patchy and often non- } \\
\text { existent. General } \\
\text { instability of life }\end{array}$ & $\begin{array}{c}\text { Long-term trading relations } \\
\text { and stable ordering } \\
\text { patterns. Up front credit } \\
\text { provided on request }\end{array}$ & $\begin{array}{c}\text { Encourages long-term } \\
\text { contracts and indication of } \\
\text { demand through letters of } \\
\text { intent. Up front credit } \\
\text { provided on request }\end{array}$ \\
\hline $\begin{array}{c}\text { Poor communities defined } \\
\text { by a lack of financial, } \\
\text { physical, human and } \\
\text { social capital }\end{array}$ & $\begin{array}{c}\text { Price to cover sustainable } \\
\text { inelihoods. Developmental } \\
\text { investment in producer } \\
\text { operations and }\end{array}$ & $\begin{array}{c}\text { Minimum above market } \\
\text { prices and Social Premium } \\
\text { paid for investment in } \\
\text { business development. }\end{array}$ \\
\cline { 2 - 3 } communities & Participation builds networks \\
\cline { 2 - 3 } & \multicolumn{2}{|c|}{} \\
\hline
\end{tabular}

Figure 3 also summarises the argument, made in more detail below, that these norms compensate for some of the real world problems faced by rural producers; specifically by reducing risk and uncertainty, and alleviating the capacity constraints that otherwise prevent accumulative diversification. Having said this, the argument by no means seeks to characterise FLO Fairtrade as either perfect or a complete response to diversification barriers; particularly as its governance does little to directly build other opportunities in the local environment. Another important point is that the argument 
here relates only to small farmers and that the certification of larger plantation style production is likely to operate very differently.

\section{FLO Fairtrade Reduces Risk and Builds Producer Capacity}

While the FLO Fairtrade minimum price system returns higher income vis-à-vis market organisation (Becchetti and Costantino 2008; Utting-Chamorro 2005), guaranteed prices, up front credit and stable relationships reduce information asymmetry and the uncertainty it creates (Milford 2004, p. 59; Utting-Chamorro 2005, p. 592). For example, Bacon (2005, p. 506) notes that "Farmers selling to a cooperative connected only $\mathbf{b}$ conventional markets are four times more likely to perceive a risk of losing the title to their land due to low coffee prices than members of cooperatives connected to alternative coffee markets". Indeed, even where financial gains have been modest the contribution to stability has still been significant and highly valued by producers (Jaffee 2007).

Perhaps the most important contribution of FLO Fairtrade (DFID 2000; UttingChamorro 2005) is the payment of a Social Premium that is invested in expanding the human and physical capital of both businesses and the wider community. While investment options are chosen through local democratic decisions, spending is directed by FLO governance (FLO 2006a, pp. 9-10). Funds can be used for credit schemes, the expansion of business infrastructure as well as business development and training. Such capacity improvements are well documented in impact studies which show the development of credit schemes (Doherty and Tranchell 2005, pp. 173-174; Milford 2004, p. 53), the extension of physical infrastructure, such as roads 
(Fairtrade Foundation 2004), equipment for weighing and measuring (Parrish et al. 2005, p. 184), and improving quality of output (Reynolds et al. 2002), pest and disease control (Fairtrade Foundation 2004), as well as general increases in technological and mechanical application (Parrish et al. 2005, p. 184; Pérezgrovas and Cervantes 2002; Taylor 2002) ${ }^{14}$. It is also important to note that FLO set up a Producer Business Unit in 2005, "to provide Fairtrade-certified producers all the information they need to strengthen their businesses and seize new market opportunities" (FLO 2006b). If this is being operationalised in an adequate way, while FLO might not actively build other livelihood options, it does help to render currently available options more viable and accessible to certified producer groups.

On education, FLO recommends that the Social Premium be used to fund, "training courses in basic education; in professional skills (computer use, tailoring, carpentry, driving, management of small business for example)" as well as "practical skills for family and community service (healthcare, child care, nutrition)" (FLO 2006a, pp. 910). On this point FLO Fairtrade can be seen to contribute to the wider process of structural change as it encourages the supply of education so important in developing economic capacity (Anand and Sen 2000). Indeed, the development of general educational facilities is almost always noted by impact work (Doherty and Tranchell 2005, p. 170; Moberg 2005, p. 12; Raynolds et al. 2004, p. 1117; Ronchi 2002, pp. 7 8; Utting-Chamorro 2005, p. 594) as are the positive effects of accumulating business skills through "learning by going". For example, the National Fairtrade Coordinator

\footnotetext{
${ }^{14}$ There is evidence to suggest that cooperatives can provide access to technology for individuals from which they would otherwise be isolated (Milford 2004, p. 64). It is also worthy of note that these investments have occurred in spite of the theoretical argument that cooperatives have short-term time horizons (Porter and Scully 1987).
} 
for Dominica in the Windward Islands comments that, 'With Fairtrade, small farmers have been transformed from marginalised farmers into businessmen" (Fairtrade Foundation 2004, p. 1).

\section{FLO Fairtrade Does Not Necessarily Blunt Incentives to Diversify}

FLO Fairtrade has certainly contributed to the capacity of local economic actors, but this still leaves the argument that while there might be more opportunity for accumulative diversification under FLO governance, the payment of higher prices will blunt the incentives to carry this out. This is the position adopted by Sidwell (2008) as he recognises the need for inputs to help small producers undertake diversification, but rejects that minimum prices are necessary or desirable to achieve this. Instead, it is proposed that consumers and businesses invest in alternative certification schemes that avoid the payment of guaranteed minimum prices, and instead work to increase returns by raising product quality.

Such an argument faces two possible responses. The first is to point out that while some price increases have been seen under alternative schemes, to date these have been lower than those under Fairtrade (Bacon 2005; Raynolds et al. 2007a, p. 155). More importantly, being market based these alternative s lack the stability shown to be so important in diversification, as well as being weaker on other development inputs such as education and the health provision (Raynolds et al. 2007a, pp. 159-160). In short, while alternative schemes might be better at providing preferable returns to "conventional governance", they are currently inferior to Fairtrade at developing the capacity needed to overcome the barriers to diversification identified above. 
Secondly, there is good ground on which to deconstruct the assumption that minimum prices paid within Fairtrade governance will automatically retard incentives for good quality. This is because while FLO maintains its own quality standards ${ }^{15}$, Fairtrade is market based in that buyers are free to choose between FLO certified producers. On this basis, it would be reasonable to assume that buyers, under pressure from subsequent stages in the chain, will seek to maintain their own quality standards and thus exert a pressure for quality especially as the market develops (Smith Forthcoming). Furthermore, quality is also directly encouraged by FLO governance as producers are required to make yearly plans for business development specifically in the area of "creating and maintaining good quality" (FLO 2006a, p. 5). This does leave the potential for individual farmers to engage in free riding strategies as individuals might seek to sell their best quality products in conventional markets before offloading inferior goods through Fairtrade co-operatives (Sidwell 2008). However, while there is evidence that incentives for increasing quality at the farmer level are not always developed (Parrish et al. 2005, p. 182), farmers can still be penalised for inadequate product quality, and further incentives to raise quality are anticipated with market maturity (Bacon 2005, p. 505). In Tanzania, cooperatives have responded to wider incentives by paying price premiums to farmers for Special Grade coffee within the FLO Fairtrade framework (Parrish et al. 2005, p. 182). Indeed, professional independent evaluation has shown that the very best coffee (marginally speaking) might not come from Fairtrade certified producers, in general

\footnotetext{
${ }^{15}$ For an illustrative example see Appendix 1 from the FLO product standards for Bananas produced by small farmers' organisations.
} 
Fairtrade is of equal and often better quality than non-certified alternatives (Davids and Bolger 2004) ${ }^{16}$.

Similar to this argument is the suggestion that farmers and cooperatives will also be less inclined to leave problematic sectors (LeClair 2002) and instead invest newly available resources in intensification; especially where markets and "pull" incentive are missing (above) ${ }^{17}$. However, an important nuance is that producers are rarely able to sell all their output as Fairtrade certified (Jaffee 2007; Moberg 2005, p. 10). This is largely interpreted as a drawback of the system and is certainly the opposite of what many producers would like (Hopkins 2000). However, while minimum prices ensure that certified output is welfare enhancing vis-à-vis conventional sales, it can be argued that some such limit is beneficial. This is because while higher returns from some percentage of outputs will help alleviate capability constrains, market incentives will still operate for the rest of the output.

Indeed, analysis of the incentive systems used by the Chinese state during the liberalisation of agriculture shows that it was a mix of fixed and market prices (Qian et al. 2002) that provided the backdrop to significant expansion, increased efficiency, and concrete welfare gains (Bramall 2000; Oi 1995; Ravallion and Chen 2007). The

\footnotetext{
${ }^{16}$ A third response would be to question the assumption that consumers of Fair Trade care only about the physical component of the products. Instead, as some consumer clearly show a preference for socially embedded qualities which should be considered equally in evaluating the utility derived from consumption (Golding and Peattie 2005; Mann 2008). In this way, analysis could also consider diversification of consumption patterns in evaluating the potential of any given export.

${ }^{17}$ Indeed, there is evidence from the craft (and thus non-FLO certified) sector that because producer groups depend on northern specific organisations for access to international markets, they have not engaged in diversification strategies (Traidcraft Market Access Centre 2005, 28, cited by Le Mare 2008, p. 1928).
} 
same argument can be made in the case of quality, and while additional inputs from Fairtrade might not be invested to increase the quality of certified goods, these funds are then available for the improvement of other product lines ${ }^{18}$.

This argument is contested by Zehner (2002, p. 15) who suggests that if "distortions" are only minimal, then the added resources will not be of sufficient volume to make effective contributions to business development. However, this criticism misses the point that higher prices are not the primary element of FLO Fairtrade. As noted above, there are other inputs offered by the governance framework to overcome the problems of conventional organisation. Going further, Haynes (2006) notes that another non-financial benefit is the competition-enhancing and market-strengthening role that investments can play in building the local economy - and in this way Fairtrade should not be seen as replacing market governance, but instead building markets institutions and hence closing the gap between empirical reality and idealised market conditions.

Another factor missed by critics is the efforts taken by FLO to actively promote diversification through their governance systems. Recognising the problems of monocropping, two of the FLO product standards now suggest that:

"The producer organisation shows efforts to also promote the marketing of other crops in the farmer's rotation pattern in order to decrease economic dependency on

\footnotetext{
${ }^{18}$ On this basis it would be recommended that the FLO try to influence demand so as to balance the distribution of benefits between producer groups. This would also reduce the risk of some organisations becoming reliant on Fair Trade while others remain excluded. One possibility for such management would be to set maximum Fairtrade returns per head of certified groups after which the remaining output would have to be sold conventionally.
} 
one single crop and to give the farmers additional sources of income. Also other alternative sources of income (e.g. production of biological pest control formulations) shall be explored"19.

This last possibility highlights a move away from agricultural commodities and into the sale of processed agricultural inputs that can have tremendous multiplier effects for both agricultural and non-agricultural sectors. While this regulation does not currently emphasise that diversification should promote higher incomes or local food security ${ }^{20}$, development of such policy could be key in constructing "hubs" around which new markets and clusters can develop. This policy would be even more resistant to critique if Fairtrade was to promote the facilitation of new market opportunities by buyers and retailers currently benefiting from the use of the FLO mark.

As this argument is grounded in policy analysis, future research is clearly necessary to investigate what concrete effect such policy has had in facilitating real life change. Indeed, such an imperative applies to the entirety of the theoretical position put forward in this paper. Having said this, and despite the evidence base being small, there is some volume of empirical evidence that FLO certified producers have undertaken diversification that is potentially of the accumulative variety (and fits into one of the three classification suggested in Figure 1). According to a recent summary of literature concerned with development impact, it was noted that Fair Trade is, "contributing to the capacity to improve and diversify livelihoods" (Le Mare 2008, p.

\footnotetext{
${ }^{19}$ See the criteria stated under "Economic Development" and "Process Requirements" (FLO 2008a, 2008b).

${ }^{20}$ Local food security is of course an issue that cannot be ignored by the development agenda.
} 
1922). Returning to the specific case of the FLO, many certified cooperatives have invested in efficiency (Ronchi 2006; Taylor 2002) and quality gains (Option 1 in Figure 1 above), such as those obtained from installing the cupping facilities noted by various studies (Fairtrade Foundation 2007; Raynolds 2002, p. 17; Utting-Chamorro 2005). Indeed, some commentators suggest that it has been such improvements that have allowed producers to compete alongside and within mainstream markets (Doherty and Meehan 2006).

FLO Fairtrade certified producers have also upgraded through the value chain (Option 2). For example, the ISMAM ${ }^{21}$ coffee cooperative in Chiapas purchased a large roasting machine and created the company Mam Maple through which they now market ready-toasted, ground and packaged coffee (Milford 2004, p. 54) ${ }^{22}$. In other cases, the stability and additional resources introduced by Fairtrade have provided the opportunity for diversification into other value chains and markets (Option 3). For example, ISMAM and UCIRI $^{23}$ cooperatives in Mexico have diversified into the marketing of cocoa, honey and organic preserves (Fridell 2007, p. 188; Milford 2004, p. 54) ${ }^{24}$, while others such as CECOCAFEN ${ }^{25}$ (Nicaragua) and ISMAM have invested in eco-tourism projects (Milford 2004, p. 54; Utting-Chamorro 2005, p. 592). In the same light, numerous groups have moved into organic production, and while some of

\footnotetext{
${ }^{21}$ Indigenas de la Sierra Madre de Motozintla.

${ }^{22}$ It is argued that such a strategy is problematic as coffee is best roasted and packed closer to retailers (Scholer 2004). However, with modern technologies both the problems of perishability and matching products to consumer demands are far from insurmountable.

${ }^{23}$ Unión de Comunidades Indígenas de la Región del Istmo.

${ }^{24}$ Where some areas have developed specialisations in certain crops due to political factors, this has often overlapped with, or been the result of, ecological limitations on what can be successfully grown (Fridell 2007, p. 176). This is clearly important in judging the viability of diversification options.

${ }^{25}$ La Central de Cooperativas Cafetaleras del Norte.
} 
these experiments have not proved successful (Smith 2007b), others have produced financial as well as environmental and health benefits (Bacon 2005; Taylor 2002, p. 14). Furthermore, change has even included the expansion of livelihoods beyond agriculture to include artisan crafts such as soap making (Doherty and Tranchell 2005, p. 170; Ronchi 2003) and even industrial clothes production (Fridell 2007, p. 188; Smith 2007a) ${ }^{26}$.

In perhaps the most inspiring developments, institutions involved with Fairtrade have made significant contributions to developing other tertiary sectors where higher levels of skills and capabilities are required. For example, UCIRI have worked with other independent organisations to play a key role in the formation of $\mathrm{CERTIMEX}^{27}$, an ecological certification system; Comercio Justo, a Mexican Fair Trade regulatory body (Smith 2008); and Integradora Agromercados, a marketing company for Fair Trade coffee and other products such as amaranth, maguey, corn and beans (Jaffee et al. 2004, pp. 184-186; Taylor 2002, p. 8; VanderHoff Boersma 2003 cited in Fridell: 188). While these examples are limited they suggest that either extraneous variables must be found to explain how these groups have overcome the propensity of Fairtrade to retard diversification, or that, perhaps, no such tendency is inherent within the system.

\footnotetext{
${ }^{26}$ It should be noted that the attempt to move into clothing manufacture was ultimately unsuccessful. However, research show that this failure was due to the inadequacy of support offered by northern partners and not the principles of Fair Trade themselves (Smith 2007a).

${ }^{27}$ Certificadora Mexicana de Productos y Procesos Ecológicos.
} 


\section{Conclusion}

The aim of this paper was to interrogate the increasingly popular argument that the payment of Fair Trade minimum prices retards economic diversification and structural change. The first stage of this response was to underline the necessity for such change. Sus tainable development will require local economies to capture more valueadded as only endogenous growth coupled with local redistribution can reduce local poverty and redress broader inequalities. However, in order to shift away from current structures, economies must build capacity to operate effectively in new sectors by undertaking incremental diversification and increasing the amount of value-added captured by current commercial activity.

With this in mind the question becomes how best to facilitate this diversification, and the primary argument has been that while perfect free market organisation might be the ideal way to promote change, such a policy option is simply unavailable. Very often markets do not exist at all, and where markets are more complete, evidence shows that "poor" producers are unlikely to be able to respond to market incentives. This is because while they are constantly forced to forgo profitable investments to manage risk, the options for new livelihoods are further restricted by a fundamental lack of capacity inherent in the condition of poverty.

On this basis it was then suggested that in place of viewing Fair Trade as an inferior alternative to perfect free markets, a more appropriate consideration is how such governance improves diversification opportunities vis-à-vis these real world alternatives. Building on the problems identified, and using the example of FLO Fairtrade, it was argued that such governance contributes stability while at the same 
time alleviating the capacity constraints that normally hold back diversification by the poor (as summarised in Figure 3). Furthermore, while a large part of the critique is based on the deductive argument that minimum prices will retard quality improvements and promote intensification, it was suggested that empirical experience indicates this is not necessarily the case - particularly where governance stresses the need to diversify.

It is important to note that these diversification requirements are only included in two product specific standards and could perhaps be extended to all product categories where problems of oversupply are significant ${ }^{28}$. Another factor for consideration will be how these standards are audited and enforced, as well as whether capacity building inputs are adequate to facilitate such moves. Indeed many argue that FLO Fairtrade is a weaker version of the Fair Trade concept (Low and Davenport 2005; Smith 2007b), and asking how the development impact of standards can be intensified might be an important part of FLO's future. One component of this could be to ask how buyers and retailers who benefit from using the FLO Certification mark could take more responsibility for providing alternative production strategies for impoverished communities.

Finally, it must be noted that the theoretical position elaborated above has only considered small producer organisations and has not discussed the issue with reference to plantation certification. In this context, FLO governance is likely to improve working conditions and build the capabilities of local populations, but in the absence of other employment options, the contribution to diversification is likely to be

\footnotetext{
${ }^{28}$ This would of course need to be balanced by softening such standards where local and international conditions reduce such options. Another nuance would be to encourage producer to contribute to domestic food security where this is appropriate.
} 
less immediate - and the question to what extent Fair Trade governance can, or should, facilitate diversification by plantations is another issue in need of urgent consideration.

Despite these limitations, there are serious questions to be asked of the standard deductive argument that Fair Trade will necessarily retard diversification and structural change. Instead of continuing to compare such governance to idealised perfect market models, it is sugge sted that commentators evaluate Fair Trade against the real alternatives open to producers. On this basis it is suggested that, far from retarding diversification and structural change, Fair Trade might in fact contribute valuable inputs to facilitating these essential processes. However, the case made above has been one largely grounded in wider literature and theory, and it is essential that increasing amounts of hard and statistically representative evidence are gathered on this issue - a responsibility that certainly falls on the shoulders of institutions arguing that Fair Trade governance contributes to the aims of sustainable development ${ }^{29}$.

\footnotetext{
${ }^{29}$ Specifically it is suggested that FLO (who set standards) and FLO-CERT GmbH (who audit producers) collaborate to integrate a significantly intensified program of research as part of their auditing operations.
} 


\section{Cited References}

Alderman, H. and Paxson, C. H. 1992. Do the poor insure? A synthesis of the literature on risk and consumption in developing countries. Policy Research Working Paper Series 1008. Washington D.C.: World Bank.

Anand, S. and Sen, A. 2000. Human development and economic sustainability. World Development 28(12), pp. 2029-2049.

Bacon, C. 2005. Confronting the Coffee Crisis: Can Fair Trade, Organic, and Specialty Coffees Reduce Small-Scale Farmer Vulnerability in Northern Nicaragua? World Development 33(3), pp. 497-511.

Baer, W. 1972. Import Substitution and Industrialization in Latin America: Experiences and Interpretations. Latin American Research Review 7(1), pp. 95-122.

Baer, W. 1984. Industrialization in Latin America: Successes and Failures. The Journal of Economic Education 15(2), pp. 124-135.

Barratt Brown, M. 1993. Fair Trade: Reform and Realities in the International Trading System. London: Zed Books.

Becchetti, L. and Costantino, M. 2008. The Effects of Fair Trade on Affiliated Producers: An Impact Analysis on Kenyan Farmers. World Development 36(5), pp. 823-842.

Becchetti, L. and Huybrechts, B. 2008. The Dynamics of Fair Trade as a Mixed-form Market. Journal of Business Ethics 81, pp. 733-750.

Bezemer, D., Balcombe, K., Davis, J. and Fraser, I. 2005. Livelihoods and farm efficiency in rural Georgia. Applied Economics 37(15), pp. 1737-1745.

Bhagwati, J. N. 1988. Protectionism. MIT Press.

Bhargava, A., Jamison, D. T., Lau, L. J. and Murray, C. J. L. 2001. Modeling the effects of health on economic growth. Journal of Health Economics 20(3), pp. 423 440.

Bigsten, A., Collier, P., Dercon, S., Fafchamps, M., Gauthier, B., Gunning, J. W., Oduro, A., Oostendorp, R., Patillo, C., Soderbom, M., Teal, F. and Zeufack, A. 2000. Contract flexibility and dispute resolution in African manufacturing. Journal of Development Studies 36(4), pp. 1 - 37.

Bloom, D. E., Canning, D. and Sevilla, J. 2004. The Effect of Health on Economic Growth: A Production Function Approach. World Development 32(1), pp. 1-13.

Booth, P. and Whetstone, L. 2007. Half a Cheer for Fair Trade. Economic Affairs 27(2), pp. 29-36. 
Borensztein, E., De Gregorio, J. and Lee, J. W. 1998. How does foreign direct investment affect economic growth? Journal of International Economics 45(1), pp. $115-135$

Bramall, C. 2000. Sources of Chinese Economic Growth, 1978-1996. Oxford: Oxford University Press.

Bruton, H. J. 1998. A Reconsideration of Import Substitution. Journal of Economic Literature 36(2), pp. 903-936.

Chang, H.-J. 2002. Kicking Away the Ladder-Development Strategy in Historical Perspective. London: Anthem Press.

Chang, H.-J. and Grabel, I. J. 2004a. Reclaiming development from the Washington consensus. Journal of Post Keynesian Economics 27(2), pp. 273-291.

Chang, H.-J. and Grabel, I. J. 2004b. Reclaiming development: an alternative economic policy manual. London Zed Books.

Chuta, E. and Liedholm, C. 1990. Rural Small-Scale Industry: Empirical Evidence and Policy Issues. In: Eicher, C. and Staatz, A. eds. Agricultural Development in the Third World. Baltimore, MD, USA: Johns Hopkins University Press.

Collier, P. 2008. The Bottom Billion: why the poorest countries are failing and what can be done about it. Oxford: Oxford University Press.

Conley, T. and Udry, C. 2001. Social Learning Through Networks: The Adoption of New Agricultural Technologies in Ghana. American Journal of Agricultural Economics 83(3), pp. 668-673.

Davids, K. and Bolger, L. 2004. The Fair-Trade Cup: Quality and Controversy. The Coffee Review September. [Online] Available at http://www.coffeereview.com/article.cfm?ID=93. [Accessed: 18/08/09].

de Janvry, A. and Sadoulet, E. 2006. Progress in the Modeling of Rural Households' Behaviour under Market Failures. In: de Janvry, A. and Kanbur, R. eds. Poverty, Inequality and Development, Essays in Honor of Erik Thorbecke. New York: Springer.

de Mello, L. R. 1997. Foreign direct investment in developing countries and growth: A selective survey. Journal of Development Studies 34(1), pp. 1-34.

Dercon, S. and Krishnan, P. 1996. Income Portfolios in Rural Ethiopia and Tanzania: Choices and Constraints. Journal of Development Studies 32(6), pp. 850-875.

DFID 2000. Fair Trade: overview, impact challenges. London: Oxford Policy Management and Sustainable Markets Group.

DFID 2005. Growth and poverty reduction: the role of agriculture. London: UK Department for International Development. 
Doherty, B. and Meehan, J. 2006. Competing on social resources: the case of the Day Chocolate Company in the UK confectionery sector. Journal of Strategic Marketing 14(4), pp. 299-313.

Doherty, B. and Tranchell, S. 2005. New Thinking in International Trade? A Case Study of The Day Chocolate Company. Sustainable Development 13(3), pp. 166-176.

Dunkley, G. 2004. Free trade: myth, reality and alternatives. London: Zed Books.

Ellis, F. 2000. Rural livelihoods and diversity in developing countries. Oxford: Oxford University Press.

Eswaran, M. and Kotwal, A. 1989. Credit as insurance in agrarian economies. Journal of Development Economics 31(1), pp. 37-53.

Evenson, R. and Westphal, L. E. 1995. Technological Change and Technology Strategy. In: Behrman, J. and Srinivasan, T.N. eds. Handbook of Development Economics. Vol. 3A. Amsterdam: North-Hollan, pp. 2209-2229.

F.I.N.E. 2001. Fair Trade Definition and Principles. Brussels: Fair Trade Advocacy Office.

Fafchamps, M. 2003. Rural Poverty Risk and Development. Cheltenham: Elgar Publishing.

Fairtrade Foundation 2004. Fairtrade Bananas Impact Study. Fairtrade Foundation. [Online] Available at http://www.fairtrade.net/uploads/media/dominica_profile.pdf. [Accessed: 08/06/08].

Fairtrade Foundation 2007. Gumutindo Coffee Co-operative Enterprises Ltd, Uganda. London: Fairtrade Foundation. [Online] Available at http://www.fairtrade.org.uk/producers/coffee/gumutindo_coffee_cooperative_uganda/ default.aspx.

Fitter, R. and Kaplinsky, R. 2001. Who Gains from Product Rents as the Coffee Market becomes more Differentiated? A Value Chain Analysis observed in other agricultural based value chains IDS Bulletin 33(3), pp. 69-82.

FLO 2006a. Explanatory Document for the Generic Fairtrade Standard For Small Farmers' Organisations.

FLO 2006b. Producer Business Unit [Online]. Available at: http://www.fairtrade.net/producer_business.html [Accessed: 16/02/09].

FLO 2007. Shaping Global Partnerships: Fairtrade Labelling Organization International Annual Report 2006/07. Bonn: Fairtrade Labelling Organizations International. 
FLO 2008a. Fairtrade Standards for Dried Fruit For Small Farmers' Organizations. Bon: Fairtrade Labelling Organizations International.

FLO 2008b. Fairtrade Standards Fresh Fruit (except Bananas) and Fresh Vegetables for Small Farmers' Organisations. Bon: Fairtrade Labelling Organizations International.

Frank, A. G. 1966. The Development of Underdevelopment. Monthly Review 18(September).

Fridell, G. 2007. Fair Trade Coffee: The prospects and pitfalls of market driven justice. London: University of Toronto.

Gereffi, G., Humphrey, J. and Sturgeon, T. 1995. The governance of global value chains. Review of International Political Economy 12(1), pp. 78-104.

Gereffi, G. and Memedovic, O. 2003. The Global Apparel Value Chain: What Prospects for Upgrading by Developing Countries. Vienna: United Nations Industrial Development Organisation.

Gilbert, A. 1988. Home enterprises in poor urban settlements: constraints, potentials and policy options. Regional Development Dialogue 9(4), pp. 21-39.

Golding, K. and Peattie, K. 2005. In search of a golden blend: perspectives on the marketing of fair trade coffee. Sustainable Development 13(3), pp. 154-165.

Granovetter, M. 1985. Economic Action and Social Structure: The Problem of Embeddedness. The American Journal of Sociology 91(3), pp. 481-510.

Hall, R. B. and Biersteker, T. F. 2002. The Emergence of Private Authority in Global Governance. Cambridge: Cambridge University Press.

Hausmann, R. and Rodrik, D. 2003. Economic Development as Self-Discovery. Journal of Development Economics 72(2), pp. 603-633.

Hayes, M. 2006. On the efficiency of fair trade. Review of Social Economy 64(4), pp. 44-468.

Hayes, M. G. 2008. Fighting the Tide: Alternative Trade Organizations in the Era of Global Free Trade - A Comment. World Development 36(12), pp. 2953-2961.

Hira, A. and Ferrie, J. 2006. Fair Trade: Three Key Challenges for Reaching the Mainstream. Journal of Business Ethics 63, pp. 107-118.

Hoff, K. and Stiglitz, J. E. 1990. Introduction: Imperfect Information and Rural Credit Markets - Puzzles and Policy Perspectives. World Bank Economic Review 4(3), pp. 235-250.

Hopkins, R. 2000. Impact Assessment of Oxfam Fair Trade, Final Report Oxfam Fair Trade Programme. Oxford: Oxfam. 
Hymer, S. and Resnick, S. 1969. A Model of an Agrarian Economy With NonAgricultural Activities. American Economic Review 59(4), pp. 493-506.

Imbs, J. and Wacziarg, R. 2003. Stages of Diversification. American Economic Review 93(1), pp. 63-86.

Inglehart, R. and Baker, W. E. 2000. Modernization, Cultural Change, and the Persistence of Traditional Values. American Sociological Review 65(1), pp. 19-51.

Jaffee, D. 2007. Brewing Justice: Fair Trade Coffee, Sustainability, and Survival. London: University of California Press.

Jaffee, D., Jack R. Kloppenburg, J. and Monroy, M. B. 2004. Bringing the 'Moral Charge' Home: Fair Trade within the North and within the South. Rural Sociology 69(2), pp. 169-196.

Kaplinsky, R. and Morris, M. 2002. A Handbook for Value Chain Research. Institute of Development Studies. [Online] Available at http://www.seepnetwork.org/files/2303_file_Handbook_for_Value_Chain_Research.p df.

Kay, C. 2002. Why East Asia overtook Latin America: agrarian reform, industrialisation and development. Third World Quarterly 23, pp. 1073-1102.

Kazianga, H. and Udry, C. 2006. Consumption smoothing? Livestock, insurance and drought in rural Burkina Faso. Journal of Development Economics 79, pp. 413-446.

Kilian, B., Jones, C., Pratt, L. and Villalobos, A. 2006. Is sustainable agriculture a viable strategy to improve farm income in Central America? A case study on coffee. Journal of Business Research 59(3), pp. 322-330.

Klinger, B. and Lederman, D. 2004. Discovery and Development: An Empirical Exploration of 'New' Products. Policy Research Working Paper 3450. Washington D.C.: World Bank.

Knight, F. H. 1921. Risk, Uncertainty and Profit. New York: AM Kelley.

Krueger, A. O. 1995. Trade policies and developing nations. Washington, D.C.: Brookings Institution.

Lall, S. 2000. Technological Change and Industrialization in the Asian Newly Industrializing Economies: Achievements and Challenges. In: Kim, L. and Nelson, R.R. eds. Technology, Learning and Innovation. New York: Cambridge University Press, pp. 13-68.

Le Mare, A. 2008. The impact of fair trade on social and economic development: A review of the literature. Geography Compass 2(6), pp. 1922-1942. 
LeClair, M. S. 2002. Fighting the Tide: Alternative Trade Organizations in the Era of Global Free Trade. World Development 30(6), pp. 949-958.

Lewis, W. A. 1954. Economic Development with Unlimited Supplies of Labour. The Manchester School 22(2), pp. 139-191.

Low, W. and Davenport, E. 2005. Postcards from the edge: Maintaining the 'alternative' character of fair trade. Sustainable Development 13(3), pp. 143-153.

Maizels, A. 2003. Economic Dependence on Commodities. In: Toye, J. ed. Trade and Development: Directions for the 21st Century. Cheltenham: Edward Elgar, pp. 169184.

Mann, S. 2008. Analysing fair trade in economic terms. Journal of Socio-Economics 37(5), pp. 2034-2042.

Marshall, A. 1890. Principles of Economics. London: Macmillan and Co., Ltd.

Mellor, J. W. 1976. The New Economics of Growth. New York: Cornell University Press.

Milford, A. 2004. Coffee, Co-operatives and Competition: The Impact of Fair Trade. Postterminalen, Norway: Chr. Michelsen Institute Development Studies and Human Rights.

Moberg, M. 2005. Fair Trade and Eastern Caribbean Banana Farmers: Rhetoric and Reality in the Anti-Globalization Movement. Human Organization 64(1), pp. 4-15.

Moore, G. 2004. The Fair Trade Movement: Parameters, Issues and Future Research Journal of Business Ethics 52, pp. 73-86.

Mordoch, J. and Haley, B. 2002. Analysis of the Effects of Microfinance on Poverty Reduction. NYU Wagner Working Paper No. 1014 (June).

Moschini, G. and Hennessy, D. 2001. Uncertainty, risk aversion, and risk management for agricultural producers. In: Gardner, B.L. and Rausser, G. eds. Handbook of agricultural economics. Vol. 1, Part 1. Elsevier.

Murphy, K. M., Shleifer, A. and Vishny, R. V. 1989. Industrialization and the big push. Journal of Political Economy 97(5), pp. 1003-1026.

Nicholls, A. and Opal, C. 2005. Fair trade: market-driven ethical consumption. London: Sage.

Noland, M. and Pack, H. 2003. Industrial Policy in an Era of Globalization: Lessons from Asia. Peterson Institute.

North, D. C. 1981. Structure and Change in Economic History. London: Norton. 
Ocampo, J. A. and Parra, M. A. 2003. Returning to an Eternal Debate: The Terms of Trade for Commodities in the Twentieth Century. . CEPAL - SERIE Informes y estudios especiales No. 5. Santiago: United Nations Publications.

Oi, J. C. 1995. The Role of the Local State in China's Transitional Economy. The China Quarterly (144), pp. 1132-1149.

Oxfam 2002. Mugged: Poverty in your coffee cup. Oxfam.

Parrish, B. D., Luzadis, V. A. and Bentley, W. R. 2005. What Tanzania's coffee farmers can teach the world: A performance-based look at the fair trade-free trade debate. Sustainable Development 13(3), pp. 177-189.

Pérezgrovas, V. and Cervantes, E. 2002. Poverty alleviation through participation in fair trade coffee networks: The Case of Union Majomut, Chiapas and Mexico. Fair Trade Research Group Colorado State University. [Online] Available at http://www.colostate.edu/Depts/Sociology/FairTradeResearchGroup.

Peter, B. R. H. 1992. The appropriate role of agricultural insurance in developing countries. Journal of International Development 4(6), pp. 567-581.

Polanyi, K. 1985 [1944]. The Great Transformation. Boston: Beacon Press.

Porter, M. E. 1990. The competitive advantage of nations. London Macmillan.

Porter, M. E. 2000. Attitudes, Values, Beliefs, and the Microeconomics of Prosperity. In: Harrison, L.E. and Huntington, S.P. eds. Culture Matters: How Values Shape Human Progress. New York: Basic Books.

Porter, P. and Scully, G. 1987. Economic efficiency in cooperatives. The Journal of Law and Economics 30, pp. 409-512.

Powell, W. W. 1991. Markets, Hierarchies and Networks. In: Thompson, G. ed. Neither market nor hierarchy: network forms of organization. London: Sage.

Prebisch, R. 1950. The Economic Development of Latin America and Its Principal Problems. Economic Bulletin for Latin America 7.

Prebisch, R. 1963. Towards a Dynamic Development Policy for Latin America. New York: United Nations.

Putnam, R. D. 2001. Social capital: Measurement and consequences. In: Helliwell, J.F. ed. The contribution of human and social capital to sustained economic growth and well-being Ottawa: Human Resources Development Canada, pp. 117- 135.

Qian, Y., Roland, G. and Xu, C. eds. 2002. Coordinating Changes in M-form and Uform Organizations. Nobel Symposium. Harvard.

Ravallion, M. and Chen, S. 2007. China's (uneven) progress against poverty. Journal of Development Economics 82, pp. 1-42. 
Raynolds, L., Douglas, M. and Taylor, P. L. 2004. Fair Trade Coffee: Building Producer Capacity via Global Networks. Journal of International Development 16, pp. 1109-1121.

Raynolds, L. T. 2002. Poverty Alleviation Through Participation in Fair Trade Coffee Networks: Existing Research and Critical Issues. Fair Trade Research Group Colorado State University. [Online] Available at http://www.colostate.edu/Depts/Sociology/FairTradeResearchGroup/doc/rayback.pdf.

Raynolds, L. T., Murray, D. and Heller, A. 2007a. Regulating sustainability in the coffee sector: A comparative analysis of third-party environmental and social certification initiatives. Agriculture and Human Values 24(2), pp. 147-163.

Raynolds, L. T., Murray, D. and Wilkinson, J. 2007b. Fair Trade: The challenges of transforming globalization. London: Routledge.

Reardon, T., Codron, J.-M., Busch, L., Bingen, J. and Harris, C. 2001. Global Change in Agrifood Grades and Standards: Agribusiness Strategic Responses in Developing Countries. International Food and Agribusiness Management Review 2(3/4), pp. 421435.

Reardon, T., Delgado, C. and Matlon, P. 1992. Determinants and effects of income diversification amongst farm households in Burkina Faso. Journal of Development Studies 28(2), pp. 264-296.

Rischkowsky, B., Siegmund-Schultze, M., Bednarz, K. and Killanga, S. 2006. Urban sheep keeping in West Africa: Can socioeconomic household profiles explain management and productivity? Human Ecology 34(6), pp. 785-807

Rodrik, D. 2004. Industrial Policy for the Twenty First Century. Paper prepared for UNIDO September.

Ronchi, L. 2000. Fair Trade in Costa Rica: An impact report. Economics Subject Group. Brighton: University of Sussex.

Ronchi, L. 2002. The Impact of Fair Trade on Producers and Their Organizations: A Case Study with Coocafe in Costa Rica. Brighton: University of Sussex.

Ronchi, L. 2003. Fair Trade Impact Monitoring and Evaluation Progress Report. Brighton: University of Sussex.

Ronchi, L. 2006. Fairtrade' and market failures in agricultural markets. World Bank Policy Research Working Paper 4011. New York: World Bank.

Rosenzweig, M. and Stark, O. 1989. Consumption smoothing, migration, and marriage: Evidence from rural India. Journal of Political Economy 97(4), pp. 905926. 
Scholer, M. 2004. Bitter or Better Future for Coffee Producers? International Trade Forum 2, pp. 9-13.

Schrank, A. 2004. Ready-to-Wear Development? Foreign Investment, Technology Transfer, and Learning-by-Watching in the Apparel Trade. Social Forces 83(1), pp. 123-156.

Sick, D. 2008. Coffee, farming families, and fair trade in Costa Rica: New markets, same old problems? Latin American Research Review 43(3), pp. 193-208.

Sidwell, M. 2008. Unfair Trade. London: Adam Smith Institute.

Singer, H. W. 1950. The Distribution of Gains between Investing and Borrowing Countries. American Economic Review 15, pp. 473-485.

Smith, A. M. 2007a. 'Can Fairtrade Certification Provide a Suitable Regulatory Framework for Garment Assembly in the Developing World?' Unpublished Thesis. Queen Elizabeth House, Department of International Development. University of Oxford. Oxford.

Smith, A. M. 2008. Fair Trade in the 'Periphery': The development of Comercio Justo México and the potential lessons for FLO Fairtrade. Comment and Analysis. ESRC Centre for Business Relationships, Accountability, Sustainability and Society. University of Cardiff. [Online] Available at http://www.brass.cf.ac.uk/uploads/AS1411008.pdf.

Smith, A. M. Forthcoming. Evaluating the Criticisms of Fair Trade: How strong is the argument that consumers and businesses should abandon Fair Trade as a means to socialise their economic decisions? Economic Affairs.

Smith, J. 2007b. The Search for Sustainable Markets: The Promise and Failures of Fair Trade. Culture and Agriculture 29(2), pp. 89-99.

Stiglitz, J. E. 1989. Markets, Market Failures, and Development. The American Economic Review 79(2), pp. 197-203.

Stiglitz, J. E. and Charlton, A. 2005. Fair trade for all: how trade can promote development. Oxford: Oxford University Press.

Strong, C. 1997. The role of fair trade principles within sustainable development. Sustainable Development 5(1), pp. 1-10.

Taylor, P. 2002. Poverty Alleviation Through Participation in Fair Trade Coffee Networks: Synthesis of Case Study Research Questions and Findings. Fair Trade Research Group, Colorado State University. [Online] Available at http://www.colostate.edu/Depts/Sociology/FairTradeResearchGroup/.

Thirlwall, A. P. and Hussain, M. N. 1982. The Balance of Payments Constraint, Capital Flows and Growth Rate Differences between Developing Countries. Oxford Economic Papers 34(3), pp. 498-510. 
Thompson, G. D. 1998. Consumer Demand for Organic Foods: What We Know and What We Need to Know. American Journal of Agricultural Economics 80(5).

Thorelli, H. B. 1986. Networks: Between markets and hierarchies. Strategic Management Journal 7(1), pp. 37-51.

Tran-Nguyen, A.-N. and Zampetti, A. B. 2004. Trade and Gender, Opportunities and Challenges for Developing Countries. UNCTAD/EDM/2004/2. United Nations.

Utting-Chamorro, K. 2005. Does fair trade make a difference? The case of small coffee producers in Nicaragua. Development in Practice 15(3), pp. 584 - 599.

VanderHoff Boersma, F. 2003. Poverty alleviation through participation in Fair Trade coffee networks: the case of UCIRI, Oaxaca, Mexico. Fair Trade Research Group, Colorado State University. [Online] Available at http://www.colostate.edu/Depts/Sociology/FairTradeResearchGroup/.

Wade, R. 1990. Governing the Market: Economic Theory and the Role of Government in East Asian Industrialization. Princeton: Princeton University Press.

Wade, R. 2005. Bringing the state back in: Lessons from east Asia's development experience. Internationale Politik und Gesellschaft (2), pp. 98-115.

Wallerstein, I. 1979. The Capitalist World Economy. Cambridge: Cambridge University Press.

Weinberger, K. and Lumpkin, T. A. 2007. Diversification into Horticulture and Poverty Reduction: A Research Agenda. World Development 35(8), pp. 1464-1480.

Williamson, O. 1975. Markets and Hierarchies: Analysis and Antitrust Implications. New York: Free Press.

Winters, A. L. 2003. Trade Policy as Development Policy. In: Toye, J.F.J. ed. Trade and Development: Directions for the 21st Century. Cheltenham: Edward Elgar.

Wood, A. 1997. Openness and Wage Inequality in Developing Countries: The Latin American Challenge to East Asian Conventional Wisdom. World Bank Economic Review 11(1), pp. 33-57.

Wood, A. 2003. Could Africa Be Like America. In: Pleskovic, B. ed. Annual World Bank Conference on Development Economics 2003: The New Reform Agenda Vol.1. Oxford University Press US.

Wood, A. and Mayer, J. 2001. Africa's export structure in a comparative perspective. Cambridge Journal of Economics 25, pp. 369-394.

World Bank 2008a. Agriculture for Development Policy Briefing. Washington D.C.: World Bank. 
World Bank 2008b. World Development Report 2008: Agriculture for Development. Washington D.C.: World Bank.

Zehner, D. C. 2002. An Economic Assessment of "Fair Trade" in Coffee. Chazen Web Journal of International Business Fall. 